\title{
Characterization of Uranium, Plutonium, Neptunium, and Americium in HLW Supernate for LLW Certification
}

by

\author{
J. S. Clemons
}

Westinghouse Savannah River Company

Savannah River Site

Aiken, South Carolina 29808

This paper was prepared in connection with work done under the above contract number with the U. S. Department of Energy. By acceptance of this paper, the publisher and/or recipient acknowledges the U.S. Government's right to retain a nonexclusive, royalty-free license in and to any copyright covering this paper, along with the right to reproduce and to authorize others to reproduce all or part of the copyrighted paper. 


\section{DISCLAIMER}

This report was prepared as an account of work sponsored by an agency of the United States Government. Neither the United States Government nor any agency thereof, nor any of their employees, makes any warranty, express or implied, or assumes any legal liability or responsibility for the accuracy. completeness, or usefulaess of any information. apparatus. product, or process disclosed, or represents that its use would not infringe privately owned rights. Reference herein to any specific commercial product. process, or service by trade name, trademark. manufacturer, or otherwise does not necessarily constitute or imply its endorsement, recommendation, or favoring by the United States Government or any agency thereof. The views and opinions of authors expressed berein do not necersarily state or reflect those of the United States Govemment or any agency inereof.

This report has been reproduced directly from the best available copy.

Available to DOE and DOE contractors from the Office of Scientific and Technical Lnformation. P. O. Box 62. Oak Ridge. TN 37831: prices available from (615) $576-8401$.

Available to the public from the National Technical Information Service. U. S. Departmeat of Commerce, 5285 Port Royal Rd., Springfield, VA 22161 


\section{DISCLAIMER}

Portions of this document may be illegible in electronic image products. Images are produced from the best available original document. 
HIGH LEVEL WASTE ENGINEERING

HIGH LEVEL ENGINEERING SUPPORT

CHARACTERIZATION OF URANIUM, PLUTONIUM, NEPTUNIUM, AND AMERICIUM

IN HLW SUPERNATE FOR LLW CERTIFICATION

BY

\section{J. S. CLEMMONS}

ISSUED: June 30, 1994
WSRC-TR-94-296

REVISION: 0

KEYWORDS:

Supernate

Uranium

Plutonium

Neptunium

Americium

E-Area Vaults

\section{RETENTION:}

CLASSIFICATION: $U$

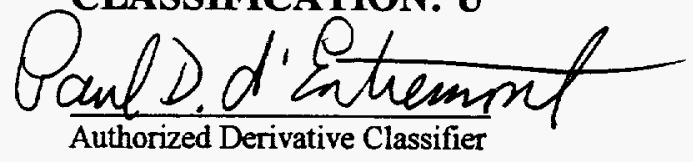

Date: fer 30,1954

Date: July 5,1944

Date: $6 / 30 / 94$

Date: $7 / 5 / 94$

Date: $7 / 14 / 94$

Date: $7 / 14 / 94$

T. M. Monahon, Manager HLWE (Approved) 


\section{INTRODUCTION}

The IS Manual requires that High Level Waste ( $\mathrm{HLW}$ ) implement a waste certification program prior to sending waste packages to the E-Area vaults. The purpose of the waste certification program is to ensure that waste packages from HLW meet the waste acceptance criteria for the E-Area Vaults. The waste acceptance criteria specifies the physical, chemical and radiological characteristics that a waste package must possess for disposal in the E-Area vaults. The waste certification program is documented in the waste certification plan.

To support the waste certification plan, the HLW supernate inventory of uranium, plutonium, neptunium and americium have been characterized. This characterization is based on the chemical, isotopic and radiological properties of these elements in $\mathrm{HLW}$ supernate. The package acceptance criteria (PAC) for sending these elements to the E-Area vaults is specified by isotope in the $1 \mathrm{~S}$ manual, procedure 3.10, Rev. 1, Table 2. This report uses process knowledge, solubility data, isotopic inventory data and sample data to determine if any isotopes of the aforementioned elements will exceed the minimum reportable quantity (MRQ) for waste packages contaminated with HLW supernate. If the MRQ can be exceeded for a particular nuclide, then a method for estimating the waste package content is provided. For information on MRQ and shipping manifests, see IS manual, procedure WAC 3.10, Rev. 1

\section{SUMMARY AND CONCLUSIONS}

Waste packages contaminated from $\mathrm{HLW}$ supernate do not contain sufficient ${ }^{233} \mathrm{U},{ }^{234} \mathrm{U},{ }^{235} \mathrm{U}$, ${ }^{236} \mathrm{U},{ }^{238} \mathrm{U},{ }^{239} \mathrm{Pu},{ }^{240} \mathrm{Pu},{ }^{241} \mathrm{Pu},{ }^{242} \mathrm{Pu}$ or ${ }^{241} \mathrm{Am}$ to warrant separate reporting on the shipping manifest. Calculations show that, on average, more than 100 gallons of supernate is required to exceed the PAC for each of these nuclides. Thus it is highly unlikely that the PAC would be exceeded for these nuclides and unlikely that the MRQ would be exceeded. These nuclides should be manifested as zero for waste packages contaminated with HLW supernate.

The only actinide isotopes that may exceed the MRQ, for the PAC limits contained in IS manual, procedure WAC 3.10, Rev. 1, are ${ }^{237} \mathrm{~Np}$ and ${ }^{238} \mathrm{Pu}$. Because these latter two isotopes will on average be bound by the ${ }^{137} \mathrm{Cs}$ content, exceeding the PAC limits is considered unlikely. The recommended method to calculate the amount of these two isotopes in waste packages contaminated with $\mathrm{HLW}$ supernate is to ratio them to the measured ${ }^{137} \mathrm{Cs}$ activity. The recommended ratios are $1 \mathrm{E}-7$ and 0.0046 for ${ }^{237} \mathrm{~Np}$ and ${ }^{238} \mathrm{Pu}$, respectively. Improved characterization of the ${ }^{23} \mathrm{~Np}$ content may eliminate the need for recording it on the manifests for future waste packages. No fissile isotope ${ }^{233} \mathrm{U},{ }^{23}{ }^{5} \mathrm{U},{ }^{239} \mathrm{Pu}$ or ${ }^{241} \mathrm{Pu}$ ), or combination of fissile isotopes was found in sufficient concentration to exceed the WAC 3.10 nuclear safety limit. 
WSRC-TR-94-296

Rev. 0

Page 3 of 25

\section{DISCUSSION}

The actinide inventory in $\mathrm{HLW}$ is a direct reflection of the nuclear material processing that occurred in $\mathrm{F}$ and $\mathrm{H}$-Canyon. For example, if highly enriched uranium was processed in the canyon, then uranium losses to waste will be highly enriched. Essentially all actinides present in $\mathrm{HLW}$ resulted from material sent to waste from $\mathrm{F}$ and $\mathrm{H}$-Canyon.

The following sections describe the $\mathrm{HLW}$ inventory of uranium, plutonium, neptunium, and americium. The origin of the subject actinides is detailed, with an emphasis on the method of production. This provides the basis for their existence in HLW. Results from technical studies on the solubility of the actinides are given to provide the basis for their abundance in HLW supernate and HLW supernate sample data is provided to demonstrate that the solubility data is reasonable and valid. The HLW actinide inventory is also provided on an activity basis to identify the major alpha emitters.

The minimum and average volume of supernate in each tank required to exceed the Low Activity Waste Vault package limit [10] for the isotopes of the subject actinides were used to determine if the MRQ for that isotope can be exceeded. The minimum and average volumes were calculated assuming the specific actinide was at its solubility limit. If the average volume was greater than 100 gallons, it is not considered likely that the MRQ can be exceeded. Solubility limits for uranium and plutonium were used to determine the amount of supernate necessary to reach the nuclear safety limit of 50 grams of enriched ${ }^{235} \mathrm{U}$ fissile gram equivalent per container.

\section{SOURCES OF ACTINIDES IN HLW}

\section{Uranium}

Uranium is found in nature and is considered to be more plentiful than mercury, antimony, silver or cadmium. Uranium has sixteen isotopes, all of which are radioactive. Naturally occurring uranium has only three isotopes, ${ }^{238} \mathrm{U},{ }^{235} \mathrm{U}$ and ${ }^{234} \mathrm{U}$, with nominal weight percents of 99.2830 , 0.7110 and 0.0054 respectively [1]. Studies show that the percentage weight of ${ }^{235} U$ in natural uranium can vary by as much as $0.1 \%$ depending on the source. The D.O.E. has adopted the value of 0.711 as the "official" percentage of ${ }^{235} \mathrm{U}$ in natural uranium [1]. Of the 16 isotopes of uranium, only 5 are present in sufficient quantity in $\mathrm{HLW}$ to be of concern. These are ${ }^{233} \mathrm{U},{ }^{234} \mathrm{U}$, ${ }^{235} \mathrm{U},{ }^{236} \mathrm{U}$ and ${ }^{238} \mathrm{U}$.

The use of uranium in nuclear materials production at SRS has been extensive. In most applications, the uranium isotopic distribution was quite different from that found in nature. The weight percentage of naturally occurring uranium isotopes were manipulated by physical processes to suit the application need. For example, in ${ }^{239} \mathrm{Pu}$ production, a high content of ${ }^{238} \mathrm{U}$ is desired. Thus uranium depleted in ${ }^{235} \mathrm{U}$ was most often used as the target material. This is typical 
of waste from PUREX reprocessing. As a fuel, a higher than natural content of ${ }^{235} \mathrm{U}$ is desired. Thus uranium enriched in ${ }^{235} \mathrm{U}$ was used. This is typical of $\mathrm{HM}$ reprocessing.

Recovery and reuse of enriched uranium fuel and special production campaigns produced the uranium isotopes ${ }^{236} \mathrm{U}$ and ${ }^{233} \mathrm{U}$ which are not naturally occurring. During the reactor cycle, approximately $1 / 6$ of all neutrons absorbed by ${ }^{235} \mathrm{U}$ transform the isotope to ${ }^{236} \mathrm{U}$. Successive recovery and irradiation of this fuel causes a significant ingrowth of ${ }^{236} \mathrm{U}$. This is typical of $\mathrm{HM}$ reprocessing. ${ }^{233} \mathrm{U}$ was produced from irradiation of thorium. Since natural thorium is $100 \%$ ${ }^{232} \mathrm{Th}$, relatively pure ${ }^{233} \mathrm{U}$ was produced. This is typical of THOREX reprocessing.

Uranium is very soluble in acid, but relatively insoluble in alkaline solution. Prior to discharge to an HLW storage tank, acidic canyon wastes are neutralized with $\mathrm{NaOH}$. This causes the bulk of the uranium to precipitate. This precipitation occurs in the presence of numerous other elements. The small fraction of uranium that remains soluble is eventually sent to one of the HLW evaporator systems. The concentration of soluble uranium in the supernate is on the order of a few ppm [8]. The concentration of uranium in the sludge layer is dependent on the reprocessing operation in the canyon and relative losses to waste. The uranium concentration in sludge from PUREX processing is about 1000 times higher than that from other processes.

\section{Uranium-233}

${ }^{233} \mathrm{U}$ was first sent to waste in April of 1964. All ${ }^{233} \mathrm{U}$ sent to waste originated from (1) THOREX processing. There were relatively few THOREX campaigns and all were performed in H-Canyon. Thus only a few tanks contain THOREX waste and all are located in H-Area. These tanks are $11,12,13,14,15,21,22,40,42$, and 51 . Tanks 40,42 and 51 received ${ }^{233} \mathrm{U}$ from sludge transfers containing THOREX waste. The remaining tanks received fresh THOREX waste. The entire mass of ${ }^{233} U$ sent to waste is estimated at just under $11 \mathrm{~kg}$. Since $U$ is primarily insoluble in alkaline waste and a relatively small mass of ${ }^{233} \mathrm{U}$ was sent to waste, only trace amounts are expected in salt tanks.

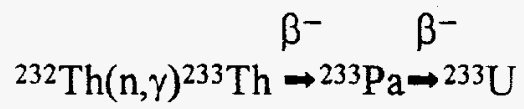

\section{Uranium-234}

${ }^{234} \mathrm{U}$ exists in nature as the third generation daughter of ${ }^{238} \mathrm{U}$ at a nominal isotopic wt. \% of 0.0054 . When uranium is enriched in ${ }^{235} \mathrm{U}$, the ${ }^{234} \mathrm{U}$ content is enriched as well. For instance, HHW uranium losses from June-1959 HM fuel reprocessing contained uranium enriched to 82.9 wt. $\%{ }^{235} \mathrm{U}$ and $1.6 \mathrm{wt} . \%{ }^{234} \mathrm{U}$. In ${ }^{233} \mathrm{U}$ production, ${ }^{234} \mathrm{U}$ is also produced by neutron capture of ${ }^{233} \mathrm{U}$ (2). Due to the limited mass of ${ }^{233} \mathrm{U}$ produced, this method of production contributed little to the overall $\mathrm{HLW}$ inventory. In high level liquid waste containing ${ }^{238} \mathrm{Pu},{ }^{234} \mathrm{U}$ is produced as the first generation daughter from ${ }^{238} \mathrm{Pu}$ alpha decay (3). ${ }^{238} \mathrm{Pu}$ alpha decay is the dominant production means in $\mathrm{HLW}$. The entire mass of ${ }^{234} \mathrm{U}$ sent to waste attributed to ${ }^{233} \mathrm{U}$ production 
and associated with enriched uranium is estimated at just under $5 \mathrm{~kg}$ [2] while the mass of ${ }^{234} \mathrm{U}$ resulting from decay of ${ }^{238} \mathrm{Pu}$ is estimated at $15 \mathrm{~kg}$ [3]. Of course this production mechanism would only be applicable to tanks containing ${ }^{238} \mathrm{Pu}$. No ${ }^{238} \mathrm{Pu}$ was sent to waste in F-Area. Similar to ${ }^{233} \mathrm{U}$, only trace amounts are expected in salt tanks.

$$
{ }^{233} \mathrm{U}(\mathrm{n}, \gamma){ }^{234} \mathrm{U}
$$

$$
{ }^{238} \mathrm{Pu} \stackrel{\alpha}{\rightarrow}{ }^{234} \mathrm{U}
$$

\section{Uranium-235}

${ }^{235} \mathrm{U}$ is present in all waste tanks that contain uranium. It is most abundant in sludge tanks that received PUREX waste due to the large amount of uranium target material sent to waste. The uranium concentration in PUREX sludge is approximately 1000 times higher than the uranium concentration in non-PUREX sludge. ${ }^{235} \mathrm{U}$ losses from PUREX reprocessing is estimated at 585 $\mathrm{kg}$, with the majority of the loss $(536 \mathrm{~kg})$ occurring in F-AREA. The majority of this ${ }^{235} \mathrm{U}$ is associated with depleted uranium. ${ }^{235} \mathrm{U}$ losses to waste in enriched uranium reprocessing (nonPUREX) were significant but not as great as PUREX losses. ${ }^{235} \mathrm{U}$ losses from non-PUREX reprocessing is estimated at $211 \mathrm{~kg}$. ${ }^{235} \mathrm{U}$ is also the first generation daughter of ${ }^{239} \mathrm{Pu}(4)$. Due to the long half-life of ${ }^{239} \mathrm{Pu}$, this method of ${ }^{235} \mathrm{U}$ production is insignificant when compared to losses from reprocessing.

$$
{ }^{239} \mathrm{Pu} \stackrel{\alpha}{\rightarrow}{ }^{235} \mathrm{U}
$$

\section{Uranium-236}

Significant quantities of ${ }^{236} \mathrm{U}$ only exist in waste tanks that received HM waste. HM reprocessing recovered enriched uranium fuel. This fuel was then re-used in the irradiation of targets.

Recovery and re-use of the enriched uranium fuel caused an ingrowth of ${ }^{236} \mathrm{U}$, because of ${ }^{235} \mathrm{U}$ neutron capture (5). This ingrowth of ${ }^{236} \mathrm{U}$ was utilized to produce ${ }^{237} \mathrm{~Np}$ during subsequent irradiation. The ${ }^{237} \mathrm{~Np}$ was recovered, fabricated into targets and irradiated to produce ${ }^{238} \mathrm{Pu}$. ${ }^{236} \mathrm{U}$ is also the first generation daughter product of ${ }^{240} \mathrm{Pu}(6)$. Due to the long half-life of ${ }^{240} \mathrm{Pu}$, this method of production is relatively insignificant. The total estimated mass of ${ }^{236} \mathrm{U}$ sent to waste is $76 \mathrm{~kg}$

$$
{ }^{235} \mathrm{U}(\mathrm{n}, y)^{236} \mathrm{U}
$$

$\alpha$

(6) $\quad{ }^{240} \mathrm{Pu} \rightarrow{ }^{236} \mathrm{U}$ 


\section{Uranium-238}

${ }^{238} \mathrm{U}$ is on average the most abundant uranium isotope in $\mathrm{HLW}$. This is especially true for PUREX waste. In PUREX waste, uranium is a major sludge component, usually third or fourth most abundant element. In non-PUREX waste, the ${ }^{238} \mathrm{U}$ abundance is highly variable and in many cases is second in abundance to ${ }^{235} \mathrm{U}$. This is typical of uranium losses from $\mathrm{HM}$ reprocessing of fuel and off-site material.

Total ${ }^{238} \mathrm{U}$ losses to $\mathrm{HLW}$ is estimated at $158,191 \mathrm{~kg}$, with the majority of the losses occurring is F-Area. Total uranium losses to HLW is estimated at $159,622 \mathrm{~kg}$. ${ }^{238} \mathrm{U}$ is also produced as the first generation daughter of ${ }^{242} \mathrm{Pu}(7)$. Due to the limited inventory and long half-life of ${ }^{242} \mathrm{Pu}$, this method of production is relatively insignificant.

$$
{ }^{242} \mathrm{Pu} \stackrel{\alpha}{\rightarrow}{ }^{238} \mathrm{U}
$$

\section{Plutonium}

Plutonium is formed by irradiation of uranium with neutrons. Plutonium also exists in trace quantities in naturally occurring uranium ores. There are fifteen known isotopes of plutonium, all of which are radioactive. Of the fifteen, only seven have half-lives long enough to permit accumulation. These isotopes are ${ }^{236} \mathrm{Pu},{ }^{238} \mathrm{Pu},{ }^{239} \mathrm{Pu},{ }^{240} \mathrm{Pu},{ }^{241} \mathrm{Pu},{ }^{242} \mathrm{Pu}$ and ${ }^{244} \mathrm{Pu}$.

The uses of plutonium are dependent on the isotopic make-up. At SRS, plutonium was produced in large quantities for use as a heat source and for nuclear weapons material. A few special production campaigns used plutonium as a target material for higher isotope production, but these campaigns were limited in number and mass of material.

As a heat source, plutonium with a high ${ }^{238} \mathrm{Pu}$ content is desired. As a fuel or weapon material, a high ${ }^{239} \mathrm{Pu}$ content is desired. The target material, irradiation process and separation are manipulated to produce plutonium concentrated in the desired isotope. The plutonium isotopes that were generated in quantities large enough to require characterization are ${ }^{238} \mathrm{Pu},{ }^{239} \mathrm{Pu},{ }^{240} \mathrm{Pu}$, ${ }^{241} \mathrm{Pu}$, and ${ }^{242} \mathrm{Pu}$.

Plutonium is highly soluble in acid, but primarily insoluble in alkaline. In canyon reprocessing operations, plutonium is kept dissolved in either an acid or an organic. Prior to discharge to $\mathrm{HLW}$, canyon wastes are neutralized with $\mathrm{NaOH}$. This causes the bulk of the plutonium to precipitate. The concentration of plutonium that remains soluble is normally less than one ppm. 
WSRC-TR-94-296

Rev. 0

Page 7 of 25

\section{Plutonium-238}

${ }^{238} \mathrm{Pu}$ for use as a heat source was produced at SRS in the following two step sequence:

(1a)

$$
\begin{gathered}
{ }^{235} \mathrm{U}(\mathrm{n}, \gamma)^{236} \mathrm{U}(\mathrm{n}, \gamma)^{237} \mathrm{U} \stackrel{\beta^{-}}{\Rightarrow}{ }^{237} \mathrm{~Np} \\
\beta^{-} \\
{ }^{238} \mathrm{U}(\mathrm{n}, 2 \mathrm{n})^{237} \mathrm{U} \stackrel{{ }^{237} \mathrm{~Np}}{ } \\
\beta^{-} \\
{ }^{237} \mathrm{~Np}(\mathrm{n}, \gamma)^{238} \mathrm{~Np} \stackrel{{ }^{238} \mathrm{Pu}}{ }
\end{gathered}
$$

Reprocessing of the irradiated neptunium targets was only performed in $\mathrm{H}$-Canyon, therefore ${ }^{238} \mathrm{Pu}$ sent to waste was limited to $\mathrm{H}$-Area waste tanks.

${ }^{238} \mathrm{Pu}$ is also ingrown in irradiated fuel. The nuclear reactions which produce it are the same as (1) and (2) above. Since there is no intermediate neptunium chemical separation, the ${ }^{238} \mathrm{Pu}$ is associated with relatively large amounts of ${ }^{239} \mathrm{Pu},{ }^{240} \mathrm{Pu},{ }^{241} \mathrm{Pu}$ and ${ }^{242} \mathrm{Pu}$ due to successive neutron capture. Plutonium formed in this manner is called Low Assay Plutonium (LAP). The isotopic distribution of LAP is highly variable and depends in large part on the ${ }^{235} \mathrm{U}$ and ${ }^{236} \mathrm{U}$ content of the fuel as well as the irradiation time. Prior to 1973, LAP was recovered from irradiated fuel. Since the isotopic distribution was not suitable as weapons material or as a heat source, it was discarded to waste. Reprocessing of reactor fuel only occurred in H-Canyon, therefore all LAP sent to waste was limited to H-Area waste tanks.

\section{Plutonium-239}

The most abundant plutonium isotope in $\mathrm{HLW}$ is ${ }^{239} \mathrm{Pu} .{ }^{239} \mathrm{Pu}$ is produced by neutron irradiation of ${ }^{238} \mathrm{U}$ according to the following reaction:

${ }^{238} \mathrm{U}(\mathrm{n}, \gamma)^{239} \mathrm{U} \stackrel{\beta^{-}}{\Rightarrow}{ }^{239} \mathrm{~Np} \rightarrow{ }^{-}$

A high ${ }^{239} \mathrm{Pu}$ content was mandatory for plutonium to meet weapons grade criteria. The ${ }^{239} \mathrm{Pu}$ content was kept high by limiting the irradiation time. This limited the amount of ${ }^{240} \mathrm{Pu},{ }^{241} \mathrm{Pu}$ and ${ }^{242} \mathrm{Pu}$ produced from successive neutron capture. Typical isotopic distribution for weapons grade plutonium is $93.5 \%{ }^{239} \mathrm{Pu}, 5.7 \%{ }^{240} \mathrm{Pu}, 0.7 \%{ }^{241} \mathrm{Pu}$ and $0.07 \%{ }^{242} \mathrm{Pu}$. The chemical separation of weapons grade plutonium from irradiated uranium targets is called the PUREX (Plutonium URanium EXtraction) process. 
The other source of ${ }^{239} \mathrm{Pu}$ is LAP. Similar to ${ }^{238} \mathrm{Pu}$, the isotopic content of ${ }^{239} \mathrm{Pu}$ in LAP was highly variable and depended on the ${ }^{235} \mathrm{U}$ and ${ }^{23} \mathrm{U}$ content of the fuel prior to irradiation and also the irradiation time. LAP waste was specific to H-Area waste tanks as previously mentioned.

Except for a few special reprocessing campaigns of limited duration and mass, Pu sent to F-Area waste tanks resulted primarily from PUREX reprocessing losses. Thus it follows that the isotopic distribution of plutonium in F-Area waste tanks does not deviate much from weapons grade values. PUREX reprocessing was only performed in H-Area during the first four years of canyon operation. The HLW mass inventory of ${ }^{239} \mathrm{Pu}$ is estimated to be $589 \mathrm{kgs}$ [4].

\section{Plutonium-240, -241, 242}

${ }^{240} \mathrm{Pu},{ }^{241} \mathrm{Pu}$ and ${ }^{242} \mathrm{Pu}$ are produced by successive neutron capture of ${ }^{239} \mathrm{Pu}$. As previously mentioned, ${ }^{240} \mathrm{Pu}$ exists in weapons grade $\mathrm{Pu}$ at a nominal weight percent of $5.7 \%$. ${ }^{241} \mathrm{Pu}$ and ${ }^{242} \mathrm{Pu}$ are present in considerable less quantity. These isotopes also exist in varying weight percents in LAP. In both LAP and weapons material, the quantity of ${ }^{240} \mathrm{Pu}$ produced always exceeded the amount of ${ }^{241} \mathrm{Pu}$. This condition will remain in the HLW Pu inventory because ${ }^{241} \mathrm{Pu}$ has a much shorter half-life than ${ }^{240} \mathrm{Pu}$. Because of this short half-life, over half of the ${ }^{241} \mathrm{Pu}$ originally sent to waste has decayed. The ${ }^{240} \mathrm{Pu},{ }^{241} \mathrm{Pu}$ and ${ }^{242} \mathrm{Pu} \mathrm{HLW}$ mass inventories are estimated to be 73,15 and $7 \mathrm{kgs}$ respectively [4].

Fairly pure ${ }^{242} \mathrm{Pu}$ can be produced by intense neutron irradiation of ${ }^{239} \mathrm{Pu}$. ${ }^{242} \mathrm{Pu}$ can also be formed by irradiation of ${ }^{241} \mathrm{Am}$. ${ }^{242} \mathrm{Pu}$ is used as target material for higher isotope production. Campaigns to produce ${ }^{242} \mathrm{Pu}$ were limited in number and $\mathrm{Pu}$ sent to waste from these campaigns is small relative to the weapons production and LAP losses.

\section{Americium}

Americium is produced from the decay of ${ }^{241} \mathrm{Pu}$ and ${ }^{243} \mathrm{Pu}$. ${ }^{241} \mathrm{Pu} \beta^{-}$decays to ${ }^{241} \mathrm{Am}$ and ${ }^{243} \mathrm{Pu}$ $\beta^{-}$decays to ${ }^{243} \mathrm{Am}$. Relatively pure ${ }^{241} \mathrm{Am}$ can be recovered by extraction as a decay product from plutonium over a period of years. In the major nuclear material production campaigns at SRS, relatively little americium was produced. The byproduct Am produced from the major reprocessing campaigns is predominantly ${ }^{241} \mathrm{Am}$. Significant ${ }^{243} \mathrm{Am}$ was only produced in special campaigns, such as that currently stored in F-Canyon tank 17.1. Total Am losses to HLW is estimated to be $51 \mathrm{kgs} \mathrm{[12].} \mathrm{The} \mathrm{bulk} \mathrm{of} \mathrm{this} \mathrm{mass} \mathrm{is} \mathrm{associated} \mathrm{with} \mathrm{waste} \mathrm{tank} \mathrm{sludge.}$

\section{Neptunium}

Neptunium is formed by irradiation of uranium with neutrons. Neptunium also exists in trace quantities in naturally occurring uranium ores. Only three isotopes of neptunium have half-lives

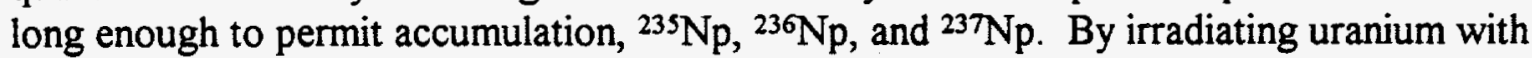
neutrons, the only isotope capable of accumulating is ${ }^{237} \mathrm{~Np}$. ${ }^{239} \mathrm{~Np}$ is produced from irradiation of ${ }^{238} \mathrm{U}$ and subsequent decay of ${ }^{239} \mathrm{U}$, however the short half-life of ${ }^{239} \mathrm{~Np}$ precludes accumulation. 
Neutron irradiaticn is not a suitable method for production of ${ }^{235} \mathrm{~Np}$ nor ${ }^{23} \mathrm{~Np}$, hence no significant quantities exist in HLW. The HLW inventory of neptunium is essentially $100 \%{ }^{237} \mathrm{~Np}$. The total ${ }^{237} \mathrm{~Np} \mathrm{HLW}$ mass inventory is estimated at $99.5 \mathrm{kgs}$ [4]. The bulk of this mass is associated with waste tank sludge.

\section{SOLUBILITY OF ACTINIDES IN ALKALINE WASTE SUPERNATE}

Acidic canyon wastes are neutralized to one molar excess $\mathrm{NaOH}$ prior to transfer to $\mathrm{HLW}$. In the $\mathrm{HLW}$ tanks, an alkaline chemistry is maintained within a balance of $\mathrm{NaOH}, \mathrm{NaNO}_{3}$, and $\mathrm{NaNO}_{2}$ to minimize corrosion of the carbon steel tanks. Numerous other salts of sodium exist in variable but usually lesser quantity.

Uranium, plutonium, neptunium and americium are only slightly soluble in alkaline chemistry. When the canyon waste streams are neutralized, the bulk of these elements co-precipitate with other waste diluents such as iron, manganese, aluminum and numerous others. Co-precipitation with other waste diluents precludes these actinides from reaching their solubility concentrations. All of the alkaline insoluble elements settle in the sludge layer at the bottom of the tank. The small fraction that remains soluble will eventually pass through an evaporator system. The following sections discuss the alkaline chemical behavior of each of these elements specifically.

\section{Uranium}

The solubility limit of uranium in alkaline chemistry has been extensively studied at SRS. Hobbs [8] investigated uranium in alkaline salt solutions (typical of SRS HLW supernate) to screen for significant factors and interactions among the major salt components and temperature. The components included in the study were hydroxide, nitrate, nitrite, aluminate, sulfate and carbonate. The following conclusions were drawn:

1. Uranium solubility is very low $(1-20 \mathrm{mg} / \mathrm{l})$ for all solutions with hydroxide concentrations from 0.1 to 17 molar.

2. Carbonate, sulfate and aluminate are not effective complexants for uranium at high hydroxide concentration.

3. Uranium solubility decreases with increasing temperature for most alkaline salt solutions.

4. Uranium solubility increases with changes in solution chemistry that reflect aging of high level waste, such as increase in carbonate and nitrite concentrations and decrease in nitrate and hydroxide concentrations.

Hobbs [8] also suggests that uranium solubility over the wide range of solution compositions is non-linear and/or there are other parameters which are important. Results from this work were consistent with his earlier uranium solubility study over a smaller range of hydroxide concentrations [6]. In his earlier work, Hobbs found uranium concentrations of up to $17.1 \mathrm{mg} / \mathrm{l}$ 
over a hydroxide concentration range of 0.1-2 molar. Similar interactions among the major salt components were also noted.

\section{Plutonium}

Similar to uranium, plutonium is only slightly soluble in alkaline waste. From solubility studies performed at SRTC, the solubility of plutonium is consistently lower than that of uranium for the range of chemical constituents present in HLW. Hobbs [6] found that between 0.1 and 2.0 molar hydroxide, the upper $95 \%$ confidence limit of plutonium solubility is $1.68 \mathrm{mg} / 1$. In actual waste tank supernate, the plutonium concentration is normally less than $0.5 \mathrm{mg} / \mathrm{l}$. The bulk of the plutonium precipitates with other waste diluents after neutralization. Coprecipitation of plutonium with waste diluents such as iron and manganese limit the plutonium from reaching its saturation concentration.

\section{Americium}

Because of the small inventory of americium in $\mathrm{HLW}$, there is little data on its chemical behavior in alkaline waste. Americium is considered to be primarily insoluble in alkaline chemistry. Hobbs [13] determined the solubility of americium in neutralized F-Canyon Tank 17.1 solution to be 0.93 $\mathrm{mg} / \mathrm{l}$. Hobbs also reported that $99.8 \%$ of the Am precipitated into a solid phase upon neutralization. The americium in this study was predominantly ${ }^{243} \mathrm{Am}$ associated with the higher isotope production campaign. Upon mixing the neutralized tank 17.1 solution with simulated waste stream solutions (fresh and aged HM and PUREX), the solubility decreased to less than the detection limit of $0.0007 \mathrm{mg} / \mathrm{l}$. The latter value is consistent with recent concentrations from sample analysis of tank 38 and 43 supernate. The Am concentrations in the supernate of these tanks was less than the detection limit of $0.0003 \mathrm{mg} / 1$ for ${ }^{241} \mathrm{Am}$ and less than $0.007 \mathrm{mg} / \mathrm{l}$ for $243 \mathrm{Am}$.

\section{Neptunium}

The solubility of $\mathrm{Np}$ in alkaline waste has not been extensively studied. There is also a lack of supernate sample data on this element. Undocumented studies on $\mathrm{Np}$ during simulated waste evaporation show that $\mathrm{Np}$ is more soluble than $\mathrm{U}, \mathrm{Pu}$ or $\mathrm{Am}$. Based on precipitation experiments by Walker [14], 70\%-99\% of the $\mathrm{Np}$ sent to waste adsorbs onto sludge particles during the precipitation process. This is consistent with the behavior of other actinides during neutralization. It is thus reasonable to estimate that $90 \%$ of the $\mathrm{Np}$ sent to waste will be associated with the sludge and $10 \%$ with the supernate. 


\section{ACTINIDE SAMPLE DATA}

Historical sample data on the actinides in HLW supernate is extremely limited. As previously demonstrated, the predominant actinides in HLW are only slightly soluble in alkaline chemistry. This fact was well understood during the SRS production years and since the emphasis was on nuclear material production and not on waste processing, extensive actinide sampling or actinide analytical work in alkaline chemistry was not a priority. In addition, the criteria for waste packages sent to the burial ground was to limit exposure to personnel, limit the heat load in waste packages and to minimize the potential for inadvertent criticality. It was readily recognized that the actinide content in waste tank supernate had no impact on these criteria. It was not until the advent of waste processing, that an emphasis for waste characterization developed. Still however, it was sufficient to recognize that the actinide content in $\mathrm{HLW}$ supernate was small. Thus it is not difficult to understand why only limited data exists.

Driven by criticality safety concerns for HLW and its processes over the last 2 to 3 years, an increased emphasis has been placed on sampling for actinides in supernate. Although the majority of the analyses looked for uranium and plutonium, as would be expected for criticality safety concerns, there are a few that were analyzed for americium and neptunium. The following sections discuss the available sample data for the subject actinides.

\section{Uranium}

Ondrejcin [18] found the uranium concentration in HLW supernate to range from $4-16 \mathrm{mg} / \mathrm{l}$ in F-Area to 0.4-6 mg/l in H-Area during a sampling effort from 1972 to 1973 . Table 1 gives the uranium analyses for several recent samples analyses by Walker [9]. Also included in Table 1 is the total alpha concentration for each of those samples with a determination of the fraction of the total alpha that is attributable to uranium. These sample results demonstrate the following characteristics of the HLW uranium inventory.

1. The concentration of uranium in HLW supernate is low and consistent with uranium solubility data.

2. The ${ }^{235} \mathrm{U}$ isotopic weight percent in supernate is similar to that of sludge for the originating waste stream, i.e., uranium in F-Area tanks is depleted and uranium in H-Area tanks is enriched.

3. Uranium is not a significant contributor to the HLW supernate alpha activity. 
WSRC-TR-94-296

Rev. 0

Page 12 of 25

Table 1. Uranium Supernate Content of HLW [9]

\begin{tabular}{cccccc} 
Tank & $\begin{array}{c}\text { Sample } \\
\mathbf{2 3 8} \mathbf{U} \\
\mathbf{m g} / \mathbf{l}\end{array}$ & $\begin{array}{c}\text { Sample } \\
\mathbf{2 3 5} \mathbf{U} \\
\mathbf{m g} / \mathbf{l}\end{array}$ & $\begin{array}{c}\text { Calculated } \\
\mathbf{U} \text { Alpha } \\
\mathbf{d} / \mathbf{m} / \mathbf{m l}\end{array}$ & $\begin{array}{c}\text { Sample } \\
\text { Alpha } \\
\mathbf{d} / \mathbf{m} / \mathbf{m l}\end{array}$ & $\begin{array}{c}\text { \% U Alpha } \\
\text { of Sample } \\
\text { Alpha }\end{array}$ \\
\hline $25 \mathrm{~F}$ & 7.4 & 0.013 & 5.59 & $5.00 \mathrm{E}+6$ & $1.12 \mathrm{E}-4$ \\
$26 \mathrm{~F}^{*}$ & 21.1 & 0.043 & 15.95 & $5.40 \mathrm{E}+6$ & $2.95 \mathrm{E}-4$ \\
$27 \mathrm{~F}$ & 2.1 & $<0.008$ & $<1.61$ & $5.00 \mathrm{E}+6$ & $<3.21 \mathrm{E}-5$ \\
$28 \mathrm{~F}$ & 1.6 & $<0.008$ & $<1.23$ & $1.80 \mathrm{E}+6$ & $<6.85 \mathrm{E}-5$ \\
$29 \mathrm{H}$ & 2.2 & 0.44 & 3.75 & $1.00 \mathrm{E}+7$ & $3.75 \mathrm{E}-5$ \\
$30 \mathrm{H}$ & 3.5 & 0.8 & 6.45 & $1.00 \mathrm{E}+7$ & $6.45 \mathrm{E}-5$ \\
$32 \mathrm{H}$ & 4 & 0.65 & 6.10 & $4.70 \mathrm{E}+6$ & $1.30 \mathrm{E}-4$ \\
$38 \mathrm{H}$ & 5.8 & 1.05 & 9.37 & $5.30 \mathrm{E}+6$ & $1.77 \mathrm{E}-4$ \\
$43 \mathrm{H}$ & 4.3 & 0.79 & 7.00 & $4.00 \mathrm{E}+6$ & $1.75 \mathrm{E}-4$
\end{tabular}

*Sample contained suspended solids due to operations which disturbed the sludge layer.

\section{Plutonium}

From available sample data [11], analyses which reported total Pu concentrations along with isotopic values for ${ }^{238} \mathrm{Pu}$ and ${ }^{239} \mathrm{Pu}$, are given in Table 2 . The Ci/gal values for ${ }^{238} \mathrm{Pu}$ and ${ }^{239} \mathrm{Pu}$ have been converted to $\mathrm{mg} / \mathrm{l}$ values for comparison to the reported solubility value of $1.68 \mathrm{mg} / \mathrm{l}$ The accuracy of these samples cannot be confirmed, however the fact that all of the concentrations reported are less than the solubility limit should still be noted. Sample data is not available for all waste tanks. The tanks with the highest estimated mass of $\mathrm{Pu}$ are listed. These tanks are 32,35 and 39.

\section{Americium}

There is very limited defensible $\mathrm{HLW}$ supernate sample data available for Am, other than the values already mention for tanks 38 and 43 . In dissolved tank 41 salt solution, Hobbs [15] found the ${ }^{241} \mathrm{Am}$ content to be less than the detection limit. That which is available from historical data [11] is listed in Table 3. As with $\mathrm{Pu}$, the accuracy of the reported Am values can not be confirmed. The $\mathrm{Ci} / \mathrm{gal}$ values reported for Am were converted to $\mathrm{mg} / \mathrm{l}$ values assuming $100 \%$ ${ }^{241} \mathrm{Am}$. Note that only one sample value exceed the reported solubility value for Am of $0.93 \mathrm{mg} / \mathrm{l}$. 
Table 2. Sample Data For Total Pu, ${ }^{238} \mathrm{Pu}$ and ${ }^{239} \mathrm{Pu}[11]$

\begin{tabular}{|c|c|c|c|c|c|c|}
\hline Tank & Date & $\begin{array}{c}\mathbf{P u} \\
(\mathrm{Ci} / \mathrm{Gal}) \\
\end{array}$ & $\begin{array}{c}{ }^{238} \mathrm{Pu} \\
\text { (Ci/Gal) } \\
\end{array}$ & $\begin{array}{l}{ }^{238} \mathbf{P u} \\
(\mathrm{mg} / \mathrm{l}) \\
\end{array}$ & $\begin{array}{c}{ }^{239} \mathrm{Pu} \\
\text { (Ci/Gal) } \\
\end{array}$ & $\begin{array}{l}{ }^{239} \mathrm{Pu} \\
(\mathrm{mg} / \mathrm{l})\end{array}$ \\
\hline $8 \mathrm{~F}$ & $7 / 1 / 76$ & $4.09 \mathrm{E}-05$ & $1.59 \mathrm{E}-07$ & $2.45 \mathrm{E}-06$ & 1.19E-08 & $5.06 \mathrm{E}-05$ \\
\hline $10 \mathrm{H}$ & $6 / 22 / 79$ & $2.90 \mathrm{E}-05$ & $1.65 \mathrm{E}-07$ & $2.55 \mathrm{E}-06$ & $5.11 \mathrm{E}-09$ & $2.17 \mathrm{E}-05$ \\
\hline $10 \mathrm{H}$ & $6 / 18 / 76$ & $4.43 \mathrm{E}-04$ & $1.62 \mathrm{E}-07$ & $2.50 \mathrm{E}-06$ & $8.52 \mathrm{E}-09$ & $3.62 E-05$ \\
\hline $13 \mathrm{H}$ & $11 / 30 / 92$ & $3.07 \mathrm{E}-05$ & $2.92 \mathrm{E}-05$ & $4.51 E-04$ & $1.53 \mathrm{E}-06$ & $6.50 \mathrm{E}-03$ \\
\hline $13 \mathrm{H}$ & $6 / 15 / 76$ & $2.05 \mathrm{E}-04$ & $4.59 \mathrm{E}-07$ & $7.08 \mathrm{E}-06$ & $1.19 \mathrm{E}-08$ & $5.06 \mathrm{E}-05$ \\
\hline $17 \mathrm{~F}$ & $7 / 20 / 76$ & $3.75 \mathrm{E}-05$ & $1.59 \mathrm{E}-07$ & $2.45 \mathrm{E}-06$ & $1.31 \mathrm{E}-07$ & $5.57 \mathrm{E}-04$ \\
\hline $18 \mathrm{~F}$ & $7 / 20 / 76$ & $3.58 \mathrm{E}-05$ & $1.59 \mathrm{E}-07$ & $2.45 \mathrm{E}-06$ & $1.19 \mathrm{E}-08$ & $5.06 \mathrm{E}-05$ \\
\hline $21 \mathrm{H}$ & $10 / 12 / 76$ & $4.09 \mathrm{E}-05$ & $1.59 \mathrm{E}-07$ & $2.45 \mathrm{E}-06$ & 1.19E-08 & $5.06 \mathrm{E}-05$ \\
\hline $22 \mathrm{H}$ & $6 / 23 / 76$ & $5.80 \mathrm{E}-04$ & $1.64 \mathrm{E}-07$ & $2.53 \mathrm{E}-06$ & $6.82 \mathrm{E}-09$ & $2.90 \mathrm{E}-05$ \\
\hline $29 \mathrm{H}$ & $7 / 14 / 76$ & $1.45 \mathrm{E}-04$ & $1.50 \mathrm{E}-07$ & $2.31 \mathrm{E}-06$ & $2.05 \mathrm{E}-08$ & $8.71 E-05$ \\
\hline $30 \mathrm{H}$ & $11 / 29 / 92$ & 1. $40 \mathrm{E}-03$ & $1.36 \mathrm{E}-03$ & 2. $10 \mathrm{E}-02$ & 4.19E-05 & $1.78 \mathrm{E}-01$ \\
\hline $31 \mathrm{H}$ & $6 / 11 / 76$ & $2.05 E-04$ & $1.36 \mathrm{E}-07$ & 2.10E-06 & $3.41 \mathrm{E}-08$ & $1.45 \mathrm{E}-04$ \\
\hline $32 \mathrm{H}$ & $11 / 29 / 92$ & $1.67 \mathrm{E}-03$ & $1.57 \mathrm{E}-03$ & $2.42 \mathrm{E}-02$ & $1.00 \mathrm{E}-04$ & $4.25 \mathrm{E}-01$ \\
\hline $32 \mathrm{H}$ & $6 / 11 / 76$ & $8.52 E-05$ & $7.84 \mathrm{E}-08$ & $1.21 \mathrm{E}-06$ & $9.21 \mathrm{E}-08$ & $3.91 \mathrm{E}-04$ \\
\hline $35 \mathrm{H}$ & $11 / 29 / 92$ & $3.24 \mathrm{E}-03$ & $2.92 \mathrm{E}-03$ & $4.51 \mathrm{E}-02$ & $3.24 \mathrm{E}-04$ & $1.38 \mathrm{E}+00$ \\
\hline $39 \mathrm{H}$ & $11 / 29 / 92$ & $4.09 \mathrm{E}-03$ & $3.76 \mathrm{E}-03$ & $5.80 \mathrm{E}-02$ & $3.27 \mathrm{E}-04$ & $1.39 \mathrm{E}+00$ \\
\hline $41 \mathrm{H}$ & $10 / 27 / 92$ & $2.78 \mathrm{E}-04$ & $2.67 \mathrm{E}-04$ & 4.12E-03 & $1.11 \mathrm{E}-05$ & $4.72 \mathrm{E}-02$ \\
\hline $48 \mathrm{H}$ & $3 / 13 / 92$ & $1.06 \mathrm{E}-06$ & $8.99 \mathrm{E}-07$ & $1.39 \mathrm{E}-05$ & $1.59 \mathrm{E}-07$ & $6.76 \mathrm{E}-04$ \\
\hline $48 \mathrm{H}$ & $3 / 13 / 92$ & $1.96 \mathrm{E}-06$ & $1.67 \mathrm{E}-06$ & $2.58 \mathrm{E}-05$ & $2.94 \mathrm{E}-07$ & $1.25 \mathrm{E}-03$ \\
\hline $51 \mathrm{H}$ & $8 / 28 / 92$ & $1.70 \mathrm{E}-05$ & $1.57 \mathrm{E}-05$ & $2.42 \mathrm{E}-04$ & $1.36 \mathrm{E}-06$ & $5.78 \mathrm{E}-03$ \\
\hline & & $1.06 \mathrm{E}-06$ & $7.84 \mathrm{E}-08$ & $1.21 \mathrm{E}-06$ & $5.11 \mathrm{E}-09$ & $2.17 E-05$ \\
\hline [aximum & & $4.09 E-03$ & $3.76 \mathrm{E}-03$ & $5.80 \mathrm{E}-02$ & $3.27 \mathrm{E}-04$ & $1.39 \mathrm{E}+00$ \\
\hline
\end{tabular}

Table 3. Sample Data For Am [11]

\begin{tabular}{cccc} 
Tank & $\begin{array}{c}\text { Sample } \\
\text { Date }\end{array}$ & $\begin{array}{c}\text { Am } \\
\text { (Ci/Gal) }\end{array}$ & $\begin{array}{c}\text { 241 Am } \\
\text { (mg/) }\end{array}$ \\
\hline IF & $2 / 20 / 69$ & $8.52 \mathrm{E}-05$ & 0.29 \\
$2 \mathrm{~F}$ & $2 / 19 / 69$ & $1.36 \mathrm{E}-04$ & 0.47 \\
5F & $2 / 28 / 69$ & $1.36 \mathrm{E}-05$ & 0.05 \\
$6 \mathrm{~F}$ & $2 / 28 / 69$ & $2.05 \mathrm{E}-04$ & 0.70 \\
$8 \mathrm{~F}$ & $3 / 7 / 69$ & $3.58 \mathrm{E}-04$ & 1.23 \\
$9 \mathrm{H}$ & $1 / 10 / 69$ & $5.11 \mathrm{E}-06$ & 0.02 \\
$10 \mathrm{H}$ & $1 / 4 / 69$ & $3.41 \mathrm{E}-06$ & 0.01 \\
$14 \mathrm{H}$ & $1 / 2 / 69$ & $3.41 \mathrm{E}-06$ & 0.01 \\
$15 \mathrm{H}$ & $12 / 18 / 68$ & $1.70 \mathrm{E}-06$ & 0.01 \\
$18 \mathrm{~F}$ & $9 / 6 / 68$ & $3.41 \mathrm{E}-05$ & 0.12
\end{tabular}


WSRC-TR-94-296

Rev. 0

Page 14 of 25

\section{Neptunium}

As with americium there is also limited HLW supernate sample data available for ${ }^{237} \mathrm{~Np}$. Salt

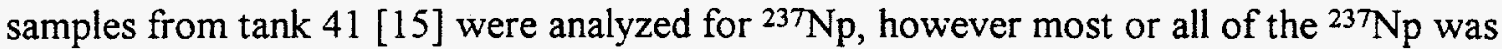
associated with the insoluble solids fraction. No values were reported for the soluble solids. This supports the contention that ${ }^{237} \mathrm{~Np}$ is associated with sludge. Historical sample data [11]

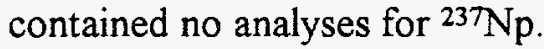

\section{ISOTOPIC LIMIT RELATIONSHIPS}

To determine the possibility of waste packages contaminated with waste tank supernate ever exceeding the LAWV limits for the subject actinides, the volume of supernate necessary to exceed the limit was calculated. This volume will be referred to as the limiting volume henceforth. For uranium, plutonium and neptunium, this was performed on a tank by tank basis [10]. The minimum limiting volume was the smallest value based on all tanks evaluated. The average limiting volume was determined from the average isotopic distribution of the total HLW inventory. Since tank by tank inventory values of americium are not available, no minimum limiting volume is available. The following sections give the limiting volumes that were determined and the bases used in their calculation. For the subject isotopes of uranium, plutonium and neptunium, an analysis of whether the minimum limiting volumes are bound by the ${ }^{137} \mathrm{Cs}$ has been performed [10]. This data is presented as well.

\section{Uranium}

The limiting volumes for uranium were determined by assuming the uranium concentration in each tank was at its solubility limit of $20 \mathrm{mg} / \mathrm{l}$ and calculating the concentration of each isotope based on the estimated sludge isotopic distribution for that tank. By dividing this concentration into the LAWV limit, the volume of supernate necessary to reach the limit was calculated. In reality, the sludge uranium isotopic distribution will most likely differ from that of the supernate, due to the blending that occurs with supernates. But because of this blending, the isotopic distribution ranges for each isotope in the supernate should be smaller than those that exist between sludges. This means that the calculation is conservative not only by assuming solubility limit concentrations, but also by assuming the range of isotopic distribution found in the sludge.

Table 4 gives the minimum and average limiting volumes for the isotopes of uranium to reach the LAWV package limits. The only uranium isotope with a minimum limiting volume below the B25 waste package volume is ${ }^{233} \mathrm{U}$. All others are in excess. The average limiting volume for ${ }^{233} \mathrm{U}$, which is based on the average isotopic distribution of the entire HLW uranium inventory, is in excess of 400 gallons. For ${ }^{234} \mathrm{U},{ }^{235} \mathrm{U},{ }^{236} \mathrm{U}$ and ${ }^{238} \mathrm{U}$ the average limiting volumes are into the thousands. 
WSRC-TR-94-296

Rev. 0

Page 15 of 25

Table 4. Uranium Limiting Volumes in HLW Supernate [10]

\begin{tabular}{lrrrrr}
\multicolumn{1}{c}{ Parameter } & ${ }^{233} \underline{\underline{U}}$ & ${ }^{234} \underline{U}$ & ${ }^{235} \underline{\mathbf{U}}$ & ${ }^{236} \underline{\mathbf{U}}$ & ${ }^{238} \underline{\mathbf{U}}$ \\
Minimum Limiting Volume (gals) & 1 & 1050 & 952 & 793 & 90500 \\
Average Limiting Volume (gals) & 436 & 521000 & 135000 & 603000 & 90900 \\
\# Tanks not bound by Cs-137 & 2 & 0 & 0 & 0 & 0 \\
Min Isotopic Wt. \% Evaluated & 0.00 & 0.00 & 0.17 & 0.00 & 10.42 \\
Max Isotopic Wt. \% Evaluated & 3.58 & 1.52 & 70.65 & 36.05 & 99.83
\end{tabular}

In addition, all but two tanks were shown to be bound by the ${ }^{137} \mathrm{Cs}$ content. This was done by comparing the limiting volume of ${ }^{137} \mathrm{Cs}$ in the waste tank to the limiting volume of the subject $U$ isotope. If a uranium isotope is bound by ${ }^{137} \mathrm{Cs}$, this means that the waste package limit for ${ }^{137} \mathrm{Cs}$ will be reached before the limit for the uranium isotope. For the two tanks not demonstrated bound by ${ }^{137} \mathrm{Cs}$, concentrations determined from previous sample data and uranium inventory estimates were substituted for the solubility limit. The volume of supernate required to reach the limit increased to values that seem extremely unlikely to enter a waste package [10].

\section{Plutonium}

The limiting volumes for plutonium were calculated in the same manner as those for uranium substituting $1.68 \mathrm{mg} / \mathrm{l}$ for the concentration. Table 5 gives the minimum and average limiting volumes for the isotopes of plutonium to reach the LAWV package limits. The minimum limiting volumes for all plutonium isotopes except ${ }^{238} \mathrm{Pu}$ are well above what would be expected in a waste package. Only three tanks were not shown to have plutonium concentrations bounded by the ${ }^{137} \mathrm{Cs}$ concentrations.

Table 5. Plutonium Limiting Volumes in HLW Supernate [10]

\begin{tabular}{lrrrrr}
\multicolumn{1}{c}{ Parameter } & ${ }^{238} \mathbf{P u}$ & ${ }^{239} \mathbf{P u}$ & ${ }^{240} \mathbf{P u}$ & ${ }^{241} \mathbf{P u}$ & ${ }^{{ }^{242} \mathbf{P u}}$ \\
Minimum Limiting Volume (gals) & 0.84 & 245 & 521 & 39 & 225865 \\
Average Limiting Volume (gals) & 5.8 & 312 & 687 & 92 & 414035 \\
\# Tanks not bound by Cs-137 & 2 & 1 & 1 & 1 & 0 \\
Min Isotopic Wt. \% Evaluated & 0.00 & 0.00 & 0.00 & 0.00 & 0.00 \\
Max Isotopic Wt. \% Evaluated & 100.00 & 94.10 & 12.05 & 4.25 & 1.66
\end{tabular}


For ${ }^{238} \mathrm{Pu}$ it is possible that a waste package could exceed the MRQ for the LAWV. Note that this possibility is specific to $\mathrm{H}$-Area waste only exclusive of ESP or ITP tanks. To manifest this isotope, the ratio of $0.0046 \mathrm{Ci}$ of ${ }^{238} \mathrm{Pu}$ per $\mathrm{Ci}$ of ${ }^{137} \mathrm{Cs}$ is recommended. This ratio was calculated using the following data:

Solubility limit of plutonium $=1.68 \mathrm{mg} / 1$ [6]

Avg. H-Area ${ }^{238} \mathrm{Pu}$ wt. $\%=23.06 \%[4]$

${ }^{238} \mathrm{Pu}$ Specific Activity $\quad=17.12 \mathrm{Ci} / \mathrm{g}[16]$

$\mathrm{H}$-Area Avg. ${ }^{137} \mathrm{Cs}$ Conc. $\quad=5.49 \mathrm{Ci} /$ gal [average of $\mathrm{H}$-Area $\mathrm{HLW}$ supernate]

\section{Neptunium}

The limiting volumes of ${ }^{237} \mathrm{~Np}$ are given in Table 6 . The limiting volumes for ${ }^{237} \mathrm{~Np}$ were calculated different from uranium and plutonium due to the lack of documented solubility data. The concentration of ${ }^{237} \mathrm{~Np}$ in each tank was calculated by distributing the entire waste tank inventory throughout the current tank waste volume [10]. The concentrations were then divided into the LAWV limit to determine the limiting volumes. Only four tanks were not shown to be bound by the ${ }^{137} \mathrm{Cs}$ concentration.

Table 6. ${ }^{237} \mathrm{~Np}$ Limiting Volumes in HLW Supernate [10]

\begin{tabular}{ll} 
Marameter & \multicolumn{2}{c|}{${ }^{237} \underline{\mathrm{Np}}$} \\
Minimum Limiting Volume (gals) & 0.18 \\
Average Limiting Volume (gals) & 5.6 \\
\# Tanks not bound by Cs-137 & 4
\end{tabular}

For ${ }^{237} \mathrm{~Np}$ it is possible that a waste package could exceed the MRQ for the LAWV. To manifest this isotope, the ratio of $1 \mathrm{E}-7 \mathrm{Ci}$ of ${ }^{237} \mathrm{~Np}$ per $\mathrm{Ci}$ of ${ }^{137} \mathrm{Cs}$ is recommended. This ratio was calculated using the following data.

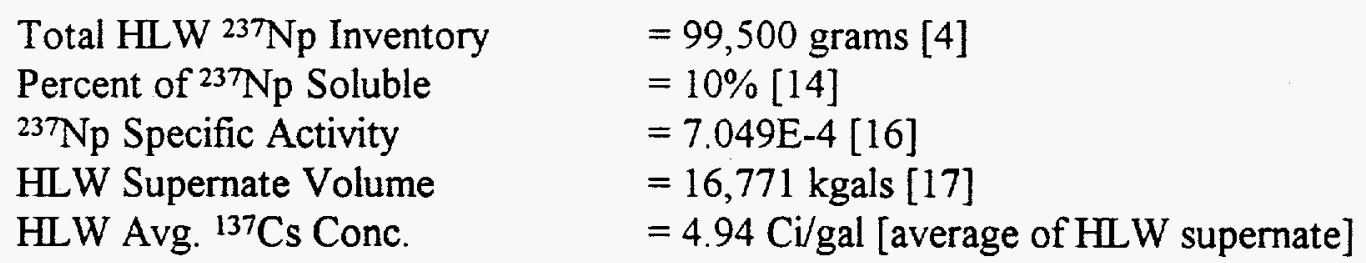

\section{Americium}

Because individual tank inventory data is not currently available for ${ }^{241} \mathrm{Am}$, minimum limiting volumes are not available. The limited sample and solubility data indicate that ${ }^{241} \mathrm{Am}$ concentrations are low. Most sample data indicates that no ${ }^{241} \mathrm{Am}$ was detected. This is consistent with Hobbs neutralization study which indicated that $99.8 \%$ of the americium precipitated as an insoluble solid. 
If americium is assumed to be at the solubility limit of $0.93 \mathrm{mg} / \mathrm{l}$ and also assumed to be $100 \%$ ${ }^{241} \mathrm{Am}$, it would require no less than 7.5 gallons of supernate to reach the LAWV limit. Since actual concentrations found in waste are usually at least two orders of magnitude lower than the solubility limit, it is considered very unlikely that ${ }^{241} \mathrm{Am}$ will ever exceed its MRQ. Based on the available information, manifesting is not recommended.

\section{ACTINIDE ISOTOPIC INVENTORY}

\section{Uranium}

The uranium isotopic distribution over all the waste tanks in $\mathrm{HLW}$ is significantly variable. However by area, there are certain characteristics that are consistent. Table 7 gives the uranium isotopic inventory associated with all tanks that received sludge from fresh canyon waste receipts or via an inter tank sludge transfer. The isotopic distribution in Table 7 is based on the total estimated inventory of uranium in the tank. This inventory may have accumulated from waste receipts with differing uranium isotopic distributions.

For tanks that did not receive sludge, such as salt tanks, the uranium isotopic inventory will be a blended mixture of the uranium isotopes for the type waste supernate that was evaporated. For this reason, salt tank uranium isotopic distributions should not have any isotopes at the endpoint of their range. For instance, the isotopic distribution of a salt tank containing evaporated F-Area HHW supernate can be expected to have a uranium isotopic distribution blended from many months of fresh HHW receipts.

In F-Area, the uranium inventory is depleted (less than natural abundance) in the ${ }^{235} \mathrm{U}$ isotope and enriched (greater than natural abundance) in the ${ }^{238} \mathrm{U}$ isotope. This is the result of using depleted uranium tails, from the enrichment process, as ${ }^{239} \mathrm{Pu}$ target material. Another contributing factor is fission burnup of ${ }^{235} \mathrm{U}$ during the irradiation process. This further depletes the ${ }^{235} \mathrm{U}$ content relative to the ${ }^{238} \mathrm{U}$ content, since the probability of fission in ${ }^{235} \mathrm{U}$ is much higher than the probability of absorption in ${ }^{238} \mathrm{U}$.

Also there is not a significant mass of ${ }^{233} \mathrm{U},{ }^{234} \mathrm{U}$ or ${ }^{236} \mathrm{U}$ in F-Area waste. This is consistent with plutonium production strategy and PUREX reprocessing. These three isotopes are only measurable in H-Area waste tanks. This is because HM and THOREX reprocessing was limited to H-Canyon. PUREX reprocessing however was not limited to F-Canyon. Between August 1955 and March 1959, PUREX reprocessing was performed in H-Canyon. This is evidenced by the high ${ }^{238} \mathrm{U}$ content of tanks 9-14. The other H-Area tanks, 40, 42 and 51, are ESP tanks and have a high ${ }^{238} \mathrm{U}$ content due to inter tank sludge transfers from F-Area tanks.

The ${ }^{239} \mathrm{U}$ content of $\mathrm{H}$-Area waste is highly variable, and is estimated to range from slightly less than $1 \mathrm{wt}$. \% to slightly more than $70 \mathrm{wt}$. \%. The fuel that was reprocessed in H-Canyon (HM 
reprocessing) began as high enriched uranium. After successive irradiations and reprocessing, the ${ }^{235} \mathrm{U}$ content decreased and the ${ }^{236} \mathrm{U}$ content increased. Thus waste received during the early years of HM reprocessing, had a higher ${ }^{235} \mathrm{U}$ content and lower ${ }^{236} \mathrm{U}$ content than in the later years of $\mathrm{HM}$ reprocessing. In addition, offsite fuels of various enrichments were processed in $\mathrm{H}$-canyon contributing to the variability of the uranium isotopic distribution.

The ${ }^{233} \mathrm{U}$ and ${ }^{234} \mathrm{U}$ isotopes are limited in mass and also limited to $\mathrm{H}$-Area waste tanks. Waste from THOREX campaigns ( ${ }^{233} \mathrm{U}$ production) was only received by a few tanks and losses were small. ${ }^{234} \mathrm{U}$ followed ${ }^{233} \mathrm{U}$ and enriched uranium, as discussed earlier. These isotopes make up a relatively minor fraction of the total uranium mass inventory.

Table 7. Uranium Waste Isotopic Distribution [4]

\begin{tabular}{|c|c|c|c|c|c|}
\hline Isotopics & $\begin{array}{r}{ }^{233} \mathrm{U} \\
\text { wt. \% } \\
\end{array}$ & $\begin{array}{r}{ }^{234} \mathrm{U} \\
\text { wt. \% } \\
\end{array}$ & $\begin{array}{r}235 U \\
\text { wt. \% } \\
\end{array}$ & $\begin{array}{c}{ }^{236} \mathrm{U} \\
\text { wt. \% } \\
\end{array}$ & $\begin{array}{r}{ }^{238} \mathrm{U} \\
\text { wt. \% } \\
\end{array}$ \\
\hline \multicolumn{6}{|l|}{$\overline{\text { By Tank: }}$} \\
\hline Minimum & 0.00 & 0.00 & 0.17 & 0.00 & 10.42 \\
\hline Average & 0.01 & 0.00 & 0.50 & 0.05 & 99.44 \\
\hline Maximum & 3.58 & 1.52 & 70.65 & 36.05 & 99.83 \\
\hline \multicolumn{6}{|l|}{ By Area: } \\
\hline -Area Avg. & 0.00 & 0.00 & 0.36 & 0.00 & 99.64 \\
\hline A-Area Avg. & 0.12 & 0.05 & 2.72 & 0.79 & 96.32 \\
\hline ESP Avg. ${ }^{*}$ & 0.01 & 0.00 & 0.51 & 0.06 & 99.43 \\
\hline
\end{tabular}

*Tanks 40, 42 and 51 are represented in the ESP Avg.

\section{Plutonium}

Similar to uranium, the plutonium isotopic distribution in F-Area waste is consistent and the distribution in H-Area waste is highly variable. Recall that F-Area waste resulted primarily from PUREX losses, while H-Area waste resulted from PUREX, THOREX, HM and off site material processing losses. Table 8 gives the plutonium isotopic distribution associated with all tanks that received sludge from fresh waste receipts or via an inter tank sludge transfer. 
WSRC-TR-94-296

Rev. 0

Page 19 of 25

Table 8. Plutonium Waste Isotopic Distribution [4]

\begin{tabular}{|c|c|c|c|c|c|}
\hline Isotopics & $\begin{array}{l}{ }^{238} \mathrm{Pu} \\
\text { wt } \%\end{array}$ & $\begin{array}{l}{ }^{239} \mathrm{Pu} \\
\text { wt } \%\end{array}$ & $\begin{array}{l}{ }^{240} \mathrm{Pu} \\
\text { wt } \%\end{array}$ & $\begin{array}{l}{ }^{241} \mathrm{Pu} \\
\text { wt } \%\end{array}$ & $\begin{array}{l}{ }^{242} \mathrm{Pu} \\
\text { wt } \%\end{array}$ \\
\hline \multicolumn{6}{|l|}{ By Tank: } \\
\hline Minimum & 0.00 & 0.00 & 0.00 & 0.00 & 0.00 \\
\hline Average & 14.31 & 73.82 & 9.14 & 1.83 & 0.91 \\
\hline Maximum & 100.00 & 94.10 & 12.05 & 4.25 & 1.66 \\
\hline
\end{tabular}

By Area:

F-Area Avg

0.00

93.59

5.93

0.31

0.16

H-Area Avg

23.06

61.75

11.05

2.80

1.34

ESP Avg.

3.48

88.65

7.07

0.36

0.44

*Tanks 40, 42 and 51 are represented in the ESP Avg.

\section{Americium}

Americium is considered to be $100 \%{ }^{241} \mathrm{Am}$

\section{Neptunium}

Neptunium is considered to be $100 \%{ }^{23} \mathrm{~Np}$

\section{ACTINIDE ACTIVITY RELATIONSHIPS}

\section{Uranium}

From an activity (curies) stand point, uranium is a minor constituent of HLW. The total HLW uranium activity equivalence is only 196 curies. For comparison, the plutonium activity equivalence is estimated to be over 3.5 million curies. Of the 196 uranium curies, ${ }^{233} \mathrm{U}$ and ${ }^{234} \mathrm{U}$ account for almost $70 \%$. On a mass basis, these isotopes are only present in trace quantities and are limited to $\mathrm{H}$-Area waste tanks.

The HLW uranium isotopic activity inventory is listed in Table 9. The total activity equivalence along with the isotopic activity by percentage is given on a per tank basis. The minimum and maximum percentages for each isotope are listed at the bottom of the table. Based on the isotopic mass distribution, a specific activity was calculated for each tank. The value listed as "Total" is the activity equivalence of the entire $\mathrm{HLW}$ uranium inventory. The values listed as average are based on the isotopic distribution of the entire $\mathrm{HLW}$ uranium inventory. 
WSRC-TR-94-296

Rev. 0

Page 20 of 25

\section{Plutonium}

The plutonium inventory on an activity basis is given in Table 10. The total estimared plutonium activity inventory is estimated at 3.5 million $\mathrm{Ci}$. From an activity stand point, ${ }^{238} \mathrm{Pu}$ and ${ }^{241} \mathrm{Pu}$ are the dominant nuclides. One third of the entire $\mathrm{HLW}$ plutonium activity is located in tank $39 \mathrm{H}$. Over $75 \%$ of the plutonium is contained in tanks $32 \mathrm{H}, 35 \mathrm{H}$ and $39 \mathrm{H}$. These tanks received fresh high waste from H-Canyon when LAP was sent to waste. F-Area waste tanks have a more uniform distribution due to the consistent PUREX processing that occurred

\section{Americium}

Americium is considered to be $100 \%{ }^{241} \mathrm{Am}$. Total estimated mass in $\mathrm{HLW}$ is $51 \mathrm{~kg}$ [12] or $175,000 \mathrm{Ci}$ at $3.432 \mathrm{Ci} / \mathrm{g}[16]$.

\section{Neptunium}

Neptunium is considered to be $100 \%{ }^{237} \mathrm{~Np}$. Total estimated mass in $\mathrm{HLW}$ is $99.5 \mathrm{~kg}$ [4] or $70 \mathrm{Ci}$ at $7.049 \mathrm{E}-4 \mathrm{Ci} / \mathrm{g}[16]$

\section{CRITICALITY SAFETY POTENTIAL}

The criticality potential for waste tanks containing HLW is considered to be incredible. In supernate, fissile material is limited by solubility to many times less than safe values. In the sludge, there is an abundance of waste diluents that behave as neutron poisons to maintain the fissile inventory subcritical. For waste packages contaminated with $\mathrm{HLW}$ supernate, it can be shown that the low concentration of fissionable materials precludes the possibility of reaching the waste package limit.

Table 11 gives the volume of supernate necessary to reach the nuclear safety limit for ${ }^{233} \mathrm{U},{ }^{235} \mathrm{U}$ ${ }^{239} \mathrm{Pu}$ and ${ }^{241} \mathrm{Pu}$. No fissile isotope or combination of fissile isotopes had a minimum volume less than the volume of a B- 25 waste container. These values were calculated assuming uranium and plutonium were at their solubility limit of $20 \mathrm{mg} / \mathrm{l}$ and $1.68 \mathrm{mg} / \mathrm{l}$ respectively. The uranium and plutonium tank inventory values were taken from reference [4] to determine the isotopic distribution. The equivalency factors to convert ${ }^{233} \mathrm{U},{ }^{239} \mathrm{Pu}$ and ${ }^{241} \mathrm{Pu}$ to ${ }^{235} \mathrm{U}$ were taken from WAC 3.10, Rev. 1. 
WSRC-TR-94-296

Rev. 0

Page 21 of 25

Table 9. HLW Uranium Isotopic Activity Inventory

\begin{tabular}{|c|c|c|c|c|c|c|c|}
\hline TANK\# & $\begin{array}{c}\text { Specific } \\
\text { Activity } \\
\text { (Ci/g) }\end{array}$ & $\begin{array}{l}\text { Total } \\
\text { Activity } \\
\text { (Ci) }\end{array}$ & $\begin{array}{c}{ }^{233} \mathrm{U} \\
\text { Activity } \\
(\%)\end{array}$ & $\begin{array}{c}{ }^{234} \mathrm{U} \\
\text { Activity } \\
(\%)\end{array}$ & $\begin{array}{c}{ }^{235} \mathrm{U} \\
\text { Activity } \\
(\%)\end{array}$ & $\begin{array}{c}{ }^{236} \mathrm{U} \\
\text { Activity } \\
(\%)\end{array}$ & $\begin{array}{c}{ }^{238} \mathrm{U} \\
\text { Activity } \\
\underline{(\%)}\end{array}$ \\
\hline IF & $3.48 \mathrm{E}-07$ & 0.46 & 0.0 & 0.0 & 3.9 & 0.0 & 96.1 \\
\hline $2 \mathrm{~F}$ & $3.48 \mathrm{E}-07$ & 0.02 & 0.0 & 0.0 & 3.9 & 0.0 & 96.1 \\
\hline $3 F$ & $3.48 \mathrm{E}-07$ & 0.05 & 0.0 & 0.0 & 3.9 & 0.0 & 96.1 \\
\hline $4 \mathrm{~F}$ & $3.43 E-07$ & 3.42 & 0.0 & 0.0 & 2.3 & 0.0 & 97.7 \\
\hline $5 \mathrm{~F}$ & $3.48 \mathrm{E}-07$ & 2.58 & 0.0 & 0.0 & 4.1 & 0.0 & 95.9 \\
\hline $6 \mathrm{~F}$ & $3.44 \mathrm{E}-07$ & 2.55 & 0.0 & 0.0 & 2.6 & 0.0 & 97.4 \\
\hline $7 F$ & $3.48 \mathrm{E}-07$ & 9.54 & 0.0 & 0.0 & 4.0 & 0.0 & 96.0 \\
\hline $8 F$ & $3.42 \mathrm{E}-07$ & 7.09 & 0.0 & 0.0 & 2.1 & 0.0 & 97.9 \\
\hline $9 \mathrm{H}$ & $3.48 \mathrm{E}-07$ & 0.03 & 0.0 & 0.0 & 3.9 & 0.0 & 96.1 \\
\hline $10 \mathrm{H}$ & $3.48 \mathrm{E}-07$ & 0.01 & 0.0 & 0.0 & 3.9 & 0.0 & 96.1 \\
\hline $11 \mathrm{H}$ & $2.10 \mathrm{E}-05$ & 4.07 & 50.2 & 41.2 & 0.8 & 6.4 & 1.4 \\
\hline $12 \mathrm{H}$ & $2.08 E-05$ & 42.90 & 89.2 & 8.4 & 0.2 & 0.7 & 1.6 \\
\hline $13 \mathrm{H}$ & 8.84E-06 & 48.91 & 83.0 & 11.7 & 0.3 & 1.2 & 3.7 \\
\hline $14 \mathrm{H}$ & $2.16 \mathrm{E}-06$ & 0.51 & 72.9 & 10.0 & 0.8 & 0.9 & 15.4 \\
\hline $15 \mathrm{H}$ & $4.51 \mathrm{E}-04$ & 18.09 & 76.7 & 21.0 & 0.3 & 2.0 & 0.0 \\
\hline $17 F$ & $3.41 \mathrm{E}-07$ & 0.09 & 0.0 & 0.0 & 1.6 & 0.0 & 98.4 \\
\hline $18 \mathrm{~F}$ & $3.42 \mathrm{E}-07$ & 0.16 & 0.0 & 0.0 & 2.0 & 0.0 & 98.0 \\
\hline $19 \mathrm{~F}$ & $3.39 \mathrm{E}-07$ & 0.02 & 0.0 & 0.0 & 1.1 & 0.0 & 98.9 \\
\hline $21 \mathrm{H}$ & $5.96 \mathrm{E}-05$ & 0.38 & 45.2 & 44.6 & 0.6 & 9.1 & 0.4 \\
\hline $22 \mathrm{H}$ & $5.22 \mathrm{E}-05$ & 1.54 & 69.8 & 25.1 & 0.4 & 4.1 & 0.6 \\
\hline $26 \mathrm{~F}$ & $3.39 \mathrm{E}-07$ & 2.04 & 0.0 & 0.0 & 1.1 & 0.0 & 98.9 \\
\hline $30 \mathrm{H}$ & $9.12 \mathrm{E}-05$ & 0.02 & 0.0 & 83.1 & 1.5 & 15.3 & 0.1 \\
\hline $32 \mathrm{H}$ & 4.12E-05 & 3.45 & 0.0 & 80.3 & 1.1 & 18.0 & 0.5 \\
\hline $33 \mathrm{~F}$ & $3.39 \mathrm{E}-07$ & 8.71 & 0.0 & 0.0 & 1.1 & 0.0 & 98.9 \\
\hline $34 \mathrm{~F}$ & $3.40 \mathrm{E}-07$ & 8.17 & 0.0 & 0.0 & 1.4 & 0.0 & 98.6 \\
\hline $35 \mathrm{H}$ & $3.06 \mathrm{E}-05$ & 3.60 & 0.0 & 75.6 & 1.3 & 22.3 & 0.8 \\
\hline $36 \mathrm{H}$ & 4.12E-05 & 0.01 & 0.0 & 72.5 & 1.4 & 25.6 & 0.5 \\
\hline $39 \mathrm{H}$ & $9.01 \mathrm{E}-05$ & 4.32 & 0.0 & 79.9 & 1.2 & 18.9 & 0.1 \\
\hline $40 \mathrm{H}$ & $7.64 \mathrm{E}-07$ & 3.68 & 38.8 & 14.0 & 1.1 & 2.3 & 43.8 \\
\hline $41 \mathrm{H}$ & $1.06 \mathrm{E}-04$ & 0.02 & 0.0 & 77.0 & 0.9 & 22.1 & 0.1 \\
\hline $42 \mathrm{H}$ & $3.45 \mathrm{E}-06$ & 11.88 & 63.3 & 23.3 & 0.6 & 3.1 & 9.6 \\
\hline $43 \mathrm{H}$ & $9.22 \mathrm{E}-05$ & 2.61 & 0.0 & 80.1 & 1.1 & 18.6 & 0.1 \\
\hline $47 \mathrm{~F}$ & $3.40 \mathrm{E}-07$ & 1.53 & 0.0 & 0.0 & 1.2 & 0.0 & 98.8 \\
\hline $51 \mathrm{H}$ & $5.39 E-07$ & 3.70 & 20.8 & 13.2 & 1.4 & 2.5 & 62.1 \\
\hline
\end{tabular}

Tank Farm

Total

Average 1.23E-06

Minimum 3.39E-07

Maximum

4.51E-04

196.16

$\begin{array}{cccccc} & 54.1 & 15.4 & 0.9 & 2.5 & 27.1 \\ 0.01 & 0.0 & 0.0 & 0.2 & 0.0 & 0.0 \\ 48.91 & 89.2 & 83.1 & 4.1 & 25.6 & 98.9\end{array}$


WSRC-TR-94-296

Rev. 0

Page 22 of 25

Table 10. HLW Plutonium Isotopic Activity Inventory

\begin{tabular}{|c|c|c|c|c|c|c|c|}
\hline TANK \# & $\begin{array}{c}\text { Specific } \\
\text { Activity } \\
\text { (Ci/g) }\end{array}$ & $\begin{array}{c}\text { Total } \\
\text { Activity } \\
\text { (Ci) }\end{array}$ & $\begin{array}{c}{ }^{238} \mathrm{Pu} \\
\text { Activity } \\
(\%)\end{array}$ & $\begin{array}{c}{ }^{239} \mathbf{P u} \\
\text { Activity } \\
(\%)\end{array}$ & $\begin{array}{c}{ }^{240} \mathrm{Pu} \\
\text { Activity } \\
(\%)\end{array}$ & $\begin{array}{c}{ }^{241} \mathrm{Pu} \\
\text { Activity } \\
(\%)\end{array}$ & $\begin{array}{c}{ }^{242} \mathrm{Pu} \\
\text { Activity } \\
(\%)\end{array}$ \\
\hline $1 F$ & 0.19 & 435 & 0.00 & 30.54 & 6.83 & 62.63 & 0.00 \\
\hline $2 F$ & 0.16 & 55 & 0.00 & 35.82 & 8.01 & 56.17 & 0.00 \\
\hline $3 F$ & 0.18 & 74 & 0.00 & 32.15 & 7.18 & 60.67 & 0.00 \\
\hline $4 F$ & 0.26 & 2619 & 0.00 & 22.82 & 5.10 & 72.08 & 0.00 \\
\hline $5 F$ & 0.23 & 1886 & 0.00 & 25.56 & 6.11 & 68.33 & 0.00 \\
\hline $6 \mathrm{~F}$ & 0.44 & 2002 & 0.00 & 12.71 & 4.42 & 82.86 & 0.01 \\
\hline $7 F$ & 0.24 & 15020 & 0.00 & 24.41 & 5.83 & 69.76 & 0.00 \\
\hline $8 F$ & 0.33 & 11251 & 0.00 & 17.60 & 4.14 & 78.25 & 0.01 \\
\hline $9 \mathrm{H}$ & 0.16 & 17 & 0.00 & 36.04 & 8.06 & 55.90 & 0.00 \\
\hline $10 \mathrm{H}$ & 0.17 & 9 & 0.00 & 34.66 & 7.75 & 57.59 & 0.00 \\
\hline $11 \mathrm{H}$ & 6.54 & 254790 & 63.94 & 0.58 & 0.37 & 35.11 & 0.00 \\
\hline $12 \mathrm{H}$ & 3.92 & 205691 & 71.85 & 1.13 & 0.62 & 26.40 & 0.00 \\
\hline $13 \mathrm{H}$ & 2.55 & 75613 & 73.79 & 1.93 & 0.80 & 23.48 & 0.00 \\
\hline $14 \mathrm{H}$ & 0.48 & 512 & 52.14 & 11.81 & 3.81 & 32.24 & 0.00 \\
\hline $15 \mathrm{H}$ & 3.23 & 84254 & 73.57 & 1.45 & 0.70 & 24.28 & 0.00 \\
\hline $17 \mathrm{~F}$ & 0.39 & 331 & 0.00 & 14.85 & 3.93 & 81.21 & 0.01 \\
\hline $18 \mathrm{~F}$ & 0.35 & 578 & 0.00 & 16.66 & 4.24 & 79.10 & 0.00 \\
\hline $19 \mathrm{~F}$ & 0.32 & 59 & 0.00 & 18.20 & 4.07 & 77.73 & 0.00 \\
\hline $21 \mathrm{H}$ & 13.11 & 1049 & 96.52 & 0.10 & 0.06 & 3.31 & 0.00 \\
\hline $22 \mathrm{H}$ & 17.12 & 1732 & 100.00 & 0.00 & 0.00 & 0.00 & 0.00 \\
\hline $26 \mathrm{~F}$ & 0.55 & 22412 & 0.00 & 10.68 & 2.39 & 86.93 & 0.00 \\
\hline $30 \mathrm{H}$ & 8.88 & 7667 & 49.98 & 0.40 & 0.29 & 49.33 & 0.00 \\
\hline $32 \mathrm{H}$ & 7.58 & 744490 & 58.81 & 0.47 & 0.35 & 40.36 & 0.00 \\
\hline $33 \mathrm{~F}$ & 0.53 & 9405 & 0.00 & 10.98 & 2.45 & 86.57 & 0.00 \\
\hline $34 \mathrm{~F}$ & 0.52 & 11642 & 0.00 & 11.17 & 2.50 & 86.33 & 0.00 \\
\hline $35 \mathrm{H}$ & 8.20 & 775605 & 57.09 & 0.42 & 0.32 & 42.16 & 0.00 \\
\hline $36 \mathrm{H}$ & 7.85 & 1092 & 60.79 & 0.44 & 0.35 & 38.42 & 0.00 \\
\hline $39 \mathrm{H}$ & 8.35 & 1168188 & 49.98 & 0.44 & 0.30 & 49.28 & 0.00 \\
\hline $40 \mathrm{H}$ & 0.48 & 8261 & 27.89 & 12.01 & 3.06 & 57.04 & 0.00 \\
\hline $41 \mathrm{H}$ & 17.12 & 219 & 100.00 & 0.00 & 0.00 & 0.00 & 0.00 \\
\hline $42 \mathrm{H}$ & 2.00 & 49906 & 70.11 & 2.57 & 0.93 & 26.39 & 0.00 \\
\hline $43 \mathrm{H}$ & 8.36 & 25207 & 59.90 & 0.42 & 0.28 & 39.40 & 0.00 \\
\hline $47 \mathrm{~F}$ & 0.49 & 19207 & 0.00 & 11.78 & 2.63 & 85.58 & 0.00 \\
\hline $51 \mathrm{H}$ & 0.45 & 11258 & 23.68 & 12.62 & 3.22 & 60.47 & 0.00 \\
\hline
\end{tabular}

Tank Farm

Total

3512538

Average

Minimum

4.40
0.16
17.12

$\begin{array}{ccc} & 55.68 & 1.04 \\ 9 & 0.00 & 0.00 \\ 1168188 & 100.00 & 36.04\end{array}$

0.47
0.00
8.06

42.80

0.00

Maximum

1168188

36.04

0.00

0.00

0.01 
WSRC-TR-94-296

Rev. 0

Page 23 of 25

Table 11. Volume of HLW Supernate to Reach WAC Nuclear Safety Limits

\begin{tabular}{|c|c|c|c|c|c|c|c|}
\hline TANK \# & $\begin{array}{l}\text { Volume of } \\
\text { Supernate } \\
\text { for }{ }^{233} \mathrm{U} \text { to } \\
\text { Reach } 50 \mathrm{~g} \\
\text { Eq. }{ }^{235} \mathrm{U} \\
\text { (gallons) }\end{array}$ & $\begin{array}{l}\text { Volume of } \\
\text { Supernate } \\
\text { for }{ }^{235} \mathrm{U} \text { to } \\
\text { Reach } 50 \mathrm{~g} \\
\text { Eq. }{ }^{235} \mathrm{U} \\
\text { (gallons) }\end{array}$ & $\begin{array}{l}\text { Volume of } \\
\text { Supernate for } \\
{ }^{233} \mathrm{U} \&^{235} \mathrm{U} \\
\text { Reach } 50 \mathrm{~g} \\
\text { Eq. }{ }^{235} \mathrm{U} \\
\text { (gallons) }\end{array}$ & $\begin{array}{l}\text { Volume of } \\
\text { Supernate } \\
\text { for }{ }^{239} \mathrm{Pu} \text { to } \\
\text { Reach 50g } \\
\text { Eq. }{ }^{235} \mathrm{U} \\
\text { (gallons) }\end{array}$ & $\begin{array}{l}\text { Volume of } \\
\text { Supernate } \\
\text { for }{ }^{241} \mathrm{Pu} \text { to } \\
\text { Reach } 50 \mathrm{~g} \\
\text { Eq. }{ }^{235} \mathrm{U} \\
\text { (gallons) }\end{array}$ & $\begin{array}{l}\text { Volume of } \\
\text { Supernate for } \\
{ }^{239} \mathrm{Pu} \& \mathrm{\&}^{241} \mathrm{Pu} \\
\text { to Reach } 50 \mathrm{~g} \\
\text { Eq. }{ }^{235} \mathrm{U} \\
\text { (gallons) }\end{array}$ & $\begin{array}{l}\text { Volume of } \\
\text { Supernate for } \\
\text { Fissile Material } \\
\text { to Reach } 50 \mathrm{~g} \\
\text { Eq. }{ }^{235} \mathrm{U} \\
\text { (gallons) }\end{array}$ \\
\hline $1 F$ & & $1.06 \mathrm{E}+05$ & $1.06 \mathrm{E}+05$ & $5.22 \mathrm{E}+03$ & $1.93 \mathrm{E}+06$ & $5.21 \mathrm{E}+03$ & $4.97 \mathrm{E}+03$ \\
\hline $2 \mathrm{~F}$ & & $1.07 \mathrm{E}+05$ & $1.07 E+05$ & $5.22 \mathrm{E}+03$ & $2.52 \mathrm{E}+06$ & $5.21 \mathrm{E}+03$ & $4.97 \mathrm{E}+03$ \\
\hline $3 \mathrm{~F}$ & & $1.07 \mathrm{E}+05$ & $1.07 E+05$ & $5.22 \mathrm{E}+03$ & $2.10 \mathrm{E}+06$ & $5.21 \mathrm{E}+03$ & $4.97 \mathrm{E}+03$ \\
\hline $4 \mathrm{~F}$ & & $1.83 E+05$ & $1.83 E+05$ & $5.23 E+03$ & $1.25 E+06$ & $5.21 E+03$ & $5.06 \mathrm{E}+03$ \\
\hline $5 F$ & & $1.01 \mathrm{E}+05$ & $1.01 E+05$ & $5.25 \mathrm{E}+03$ & $1.49 \mathrm{E}+06$ & $5.23 E+03$ & $4.97 \mathrm{E}+03$ \\
\hline $6 \mathrm{~F}$ & & $1.59 \mathrm{E}+05$ & $1.59 E+05$ & $5.46 \mathrm{E}+03$ & $6.35 E+05$ & $5.41 \mathrm{E}+03$ & $5.23 E+03$ \\
\hline $7 \mathrm{~F}$ & & $1.03 E+05$ & $1.03 E+05$ & $5.25 \mathrm{E}+03$ & $1.39 \mathrm{E}+06$ & $5.23 E+03$ & $4.98 E+03$ \\
\hline $8 \mathrm{~F}$ & & $1.96 \mathrm{E}+05$ & $1.96 \mathrm{E}+05$ & $5.27 \mathrm{E}+03$ & $8.98 E+05$ & $5.24 \mathrm{E}+03$ & $5.10 \mathrm{E}+03$ \\
\hline $9 \mathrm{H}$ & & $1.07 \mathrm{E}+05$ & $1.07 E+05$ & $5.22 E+03$ & $2.55 E+06$ & $5.21 E+03$ & $4.97 \mathrm{E}+03$ \\
\hline $10 \mathrm{H}$ & & $1.07 \mathrm{E}+05$ & $1.07 \mathrm{E}+05$ & $5.22 \mathrm{E}+03$ & $2.38 \mathrm{E}+06$ & $5.21 \mathrm{E}+03$ & $4.97 \mathrm{E}+03$ \\
\hline $11 \mathrm{H}$ & $4.33 E+05$ & $8.74 E+03$ & $8.56 E+03$ & $7.99 E+03$ & $1.01 E+05$ & $7.41 E+03$ & $3.97 \mathrm{E}+03$ \\
\hline $12 \mathrm{H}$ & $2.46 \mathrm{E}+05$ & $4.36 \mathrm{E}+04$ & $3.70 \mathrm{E}+04$ & $6.93 E+03$ & $2.24 \mathrm{E}+05$ & $6.72 E+03$ & $5.69 \mathrm{E}+03$ \\
\hline $13 \mathrm{H}$ & $6.22 \mathrm{E}+05$ & $5.04 \mathrm{E}+04$ & $4.66 \mathrm{E}+04$ & $6.21 E+03$ & $3.86 \mathrm{E}+05$ & $6.11 E+03$ & $5.40 E+03$ \\
\hline $14 \mathrm{H}$ & $2.90 \mathrm{E}+06$ & $8.17 \mathrm{E}+04$ & $7.94 \mathrm{E}+04$ & $5.44 \mathrm{E}+03$ & $1.51 \mathrm{E}+06$ & $5.42 E+03$ & $5.07 \mathrm{E}+03$ \\
\hline $15 \mathrm{H}$ & $1.32 \mathrm{E}+04$ & $9.35 E+02$ & $8.73 E+02$ & $6.55 \mathrm{E}+03$ & $2.95 E+05$ & $6.41 E+03$ & $7.68 \mathrm{E}+02$ \\
\hline $17 \mathrm{~F}$ & & $2.64 E+05$ & $2.64 \mathrm{E}+05$ & $5.32 \mathrm{E}+03$ & $7.36 \mathrm{E}+05$ & $5.28 \mathrm{E}+03$ & $5.17 \mathrm{E}+03$ \\
\hline $18 \mathrm{~F}$ & & $2.11 E+05$ & $2.11 E+05$ & $5.29 \mathrm{E}+03$ & $8.44 E+05$ & $5.26 \mathrm{E}+03$ & $5.13 E+03$ \\
\hline $19 \mathrm{~F}$ & & $3.89 \mathrm{E}+05$ & $3.89 \mathrm{E}+05$ & $5.23 E+03$ & $9.28 \mathrm{E}+05$ & $5.20 \mathrm{E}+03$ & $5.13 E+03$ \\
\hline $21 H$ & $1.70 \mathrm{E}+05$ & $3.89 \mathrm{E}+03$ & $3.80 \mathrm{E}+03$ & $2.23 \mathrm{E}+04$ & $5.33 \mathrm{E}+05$ & $2.14 \mathrm{E}+04$ & $3.23 E+03$ \\
\hline $22 \mathrm{H}$ & $1.25 \mathrm{E}+05$ & $7.12 \mathrm{E}+03$ & $6.74 E+03$ & & & & $6.74 \mathrm{E}+03$ \\
\hline $26 \mathrm{~F}$ & & $3.89 \mathrm{E}+05$ & $3.89 \mathrm{E}+05$ & $5.24 \mathrm{E}+03$ & $4.88 \mathrm{E}+05$ & $5.19 \mathrm{E}+03$ & $5.12 E+03$ \\
\hline $30 \mathrm{H}$ & & $1.06 \mathrm{E}+03$ & $1.06 \mathrm{E}+03$ & $8.61 E+03$ & $5.28 \mathrm{E}+04$ & $7.41 \mathrm{E}+03$ & $9.27 \mathrm{E}+02$ \\
\hline $32 \mathrm{H}$ & & $3.02 E+03$ & $3.02 \mathrm{E}+03$ & $8.50 E+03$ & $7.57 \mathrm{E}+04$ & $7.64 \mathrm{E}+03$ & $2.16 \mathrm{E}+03$ \\
\hline $33 \mathrm{~F}$ & & $3.89 \mathrm{E}+05$ & $3.89 \mathrm{E}+05$ & $5.24 E+03$ & $5.04 \mathrm{E}+05$ & $5.19 \mathrm{E}+03$ & $5.12 E+03$ \\
\hline $34 \mathrm{~F}$ & & $3.00 \mathrm{E}+05$ & $3.00 \mathrm{E}+05$ & $5.24 \mathrm{E}+03$ & $5.14 \mathrm{E}+05$ & $5.19 \mathrm{E}+03$ & $5.10 \mathrm{E}+03$ \\
\hline $35 \mathrm{H}$ & & $3.55 \mathrm{E}+03$ & $3.55 \mathrm{E}+03$ & $8.77 \mathrm{E}+03$ & $6.69 \mathrm{E}+04$ & $7.76 \mathrm{E}+03$ & $2.44 \mathrm{E}+03$ \\
\hline $36 \mathrm{H}$ & & $2.46 \mathrm{E}+03$ & $2.46 \mathrm{E}+03$ & $8.85 E+03$ & $7.67 \mathrm{E}+04$ & $7.93 E+03$ & $1.88 E+03$ \\
\hline $39 \mathrm{H}$ & & $1.35 \mathrm{E}+03$ & $1.35 E+03$ & $8.35 \mathrm{E}+03$ & $5.62 E+04$ & $7.27 \mathrm{E}+03$ & $1.14 E+03$ \\
\hline $40 \mathrm{H}$ & $1.54 \mathrm{E}+07$ & $1.71 E+05$ & $1.69 \mathrm{E}+05$ & $5.33 \mathrm{E}+03$ & $8.51 E+05$ & $5.30 \mathrm{E}+03$ & $5.14 E+03$ \\
\hline $41 \mathrm{H}$ & & $1.52 \mathrm{E}+03$ & $1.52 E+03$ & & & & $1.52 \mathrm{E}+03$ \\
\hline $42 \mathrm{H}$ & $2.09 \mathrm{E}+06$ & $6.82 E+04$ & $6.61 E+04$ & $5.95 \mathrm{E}+03$ & $4.39 \mathrm{E}+05$ & $5.87 E+03$ & $5.39 E+03$ \\
\hline $43 \mathrm{H}$ & & $1.36 E+03$ & $1.36 \mathrm{E}+03$ & $8.73 E+03$ & $7.02 E+04$ & $7.77 \mathrm{E}+03$ & $1.16 \mathrm{E}+03$ \\
\hline $47 \mathrm{~F}$ & & $3.46 \mathrm{E}+05$ & $3.46 \mathrm{E}+05$ & $5.24 \mathrm{E}+03$ & $5.46 E+05$ & $5.19 E+03$ & $5.11 E+03$ \\
\hline $51 H$ & $4.08 \mathrm{E}+07$ & $1.84 \mathrm{E}+05$ & $1.83 \mathrm{E}+05$ & $5.33 \mathrm{E}+03$ & $8.43 E+05$ & $5.29 \mathrm{E}+03$ & $5.15 E+03$ \\
\hline \multicolumn{8}{|l|}{ lumes } \\
\hline & $1.32 E+04$ & $9.35 E+02$ & $8.73 E+02$ & $5.22 E+03$ & $5.28 E+04$ & $5.19 E+03$ & $7.68 E+02$ \\
\hline era & $6.84 E+06$ & $1.32 \mathrm{E}+05$ & $1.30 \mathrm{E}+05$ & $6.66 E+03$ & $1.23 \mathrm{E}+05$ & $6.32 E+03$ & $6.02 E+03$ \\
\hline aximum & $4.08 E+07$ & $3.89 E+05$ & $3.89 \mathrm{E}+05$ & $2.23 E+04$ & $2.55 E+06$ & $2.14 E+04$ & $6.74 E+03$ \\
\hline
\end{tabular}




\section{REFERENCES}

[1] CRC Handbook of Chemistry and Physics, 73rd Edition, CRC Press, Inc., 1992-1993

[2] WSRC-TR-93-135, Rev. 1, "Separations Waste Sludge Spreadsheet (U)", W. S. Cavin, July 28, 1993

[3] Calculated by subtracting the current tank farm ${ }^{238} \mathrm{Pu}$ inventory [2] from the original mass of ${ }^{238} \mathrm{Pu}$ sent to waste [2].

[4] WSRC-TR-94-191, Rev. 0, "Estimated Sludge Inventory For Individual Tanks (U)", H. Tran, May 4, 1994

[5] WSRC-TR-93-433, Rev. 0, "Uranium Solubility Studies During Waste Evaporation (U)", D. G. Karraker, August 16, 1993

[6] WSRC-TR-93-056, "Solubility of Plutonium and Uranium in Alkaline Salt Solutions (U)", D. T. Hobbs, T. B. Edwards and S. D. Fleischman, February 12, 1993

[7] WSRC-RP-94-251, Rev. 0, "Evaporation Studies of Simulated Low-Heat Waste and Post-Aluminum Dissolution Waste (U)", M. J. Barnes and G. T. Chandler, March 4, 1994

[8] WSRC-TR-94-454, "Solubility of Uranium in Alkaline Salt Solutions (U)", D. T. Hobbs and T. B. Edwards, March 29, 1994

[9] WSRC-RP-93-1009, D. D. Walker, C. J. Coleman and R. A. Dewberry to S. D. Fink, "Composition of Tank Farm Supernate Samples (U)", July 16, 1993.

[10] WSRC-TR-94-227, Rev. 0, "Assessment of Uranium, Plutonium and Np-237 Content of High Level Liquid Waste on E-Area Vault Package Limits (U)", J. S. Clemmons.

June 8, 1994

[11] HLW-HLE-94-0328, J. A. Pike to M. C. Chandler, "Radio Nuclide Sample Analysis of Waste Tanks 1-51 (U)", January 24, 1994

[12] WSRC-TR-940255, "Uranium, Thorium, and TRU Inventories at SRS (U)", Ann Gibbs, May 1994.

[13] WSRC-TR-94-0252, "Solubility of Americium and Curium in Alkaline Salt Solutions (U)", D. T. Hobbs, May 17, 1994. 
WSRC-TR-94-296

Rev. 0

Page 25 of 25

[14] Laboratory Notebook DPSTN-4442, pages 62-79, D. D. Walker

[15] WSRC-TR-94-057, "Final Report: Analysis of Tank 41H Saltcake Sample \#2 and Comparison to Sample \#1 (U)", D. T. Hobbs and C. J. Coleman, January 26,1994

[16] DOE/RW-0006, Rev. 7, Integrated Data Base for 1991: U. S. Spent Fuel and Radioactive Waste Inventories, Projections, and Characteristics, October 1991

[17] WSRC-RP-94-383-5, "High Level Waste Engineering Monthly Data Report (U)", April 1994

[18] DP-1347, "Chemical Composition of Supernates Stored in SRP High Level Waste Tanks", R. S. Ondrejcin, August 1974 